\title{
Progressive decoupling between phytoplankton growth and microzooplankton grazing during an iron-induced phytoplankton bloom in the Southern Ocean (EIFEX)
}

\author{
Mikel Latasa ${ }^{1,2, *}$, Joachim Henjes ${ }^{3}$, Renate Scharek ${ }^{1}$, Philipp Assmy ${ }^{4,5}$, \\ Rüdiger Röttgers ${ }^{6}$, Victor Smetacek ${ }^{4}$ \\ ${ }^{1}$ Centro Oceanográfico de Gijón/Xixón (IEO), Avda. Príncipe de Asturias, 70 Bis, 33212 Gijón/Xixón, Spain \\ ${ }^{2}$ Institut de Ciències del Mar (CSIC), Passeig Marítim de la Barceloneta 37-49, 08003 Barcelona, Spain \\ ${ }^{3}$ IMARE - Institute for Marine Resources GmbH, Bussestrasse 27, 27570 Bremerhaven, Germany \\ ${ }^{4}$ Alfred Wegener Institute Helmholtz Center for Polar and Marine Research, Am Handelshafen 12, 27570 Bremerhaven, Germany \\ ${ }^{5}$ Norwegian Polar Institute, Fram Centre, Hjalmar Johansens gt. 14, 9296 Tromsø, Norway \\ ${ }^{6}$ Helmholtz-Zentrum Geesthacht, Centre for Materials and Coastal Research, Max-Planck-Str. 1, 21502 Geesthacht, Germany
}

\begin{abstract}
Dilution experiments were performed to quantify growth and mortality rates of phytoplankton groups (as defined by pigment markers) for $5 \mathrm{wk}$ in an iron-induced phytoplankton bloom during the European Iron Fertilization Experiment (EIFEX) conducted in the Southern Ocean. Rates could be reliably measured for the 2 main groups, diatoms and prymnesiophytes. Mean phytoplankton intrinsic growth rates were around $0.23 \mathrm{~d}^{-1}$, without a significant temporal trend. Mortality rates, however, decreased with time (from $\sim 0.3$ to $\sim 0.06 \mathrm{~d}^{-1}$ ), leading to an increase in decoupling between phytoplankton growth and microzooplankton grazing. The decrease in grazing was correlated with the decrease in concentrations of small microprotozooplankton $(<60 \mu \mathrm{m})$. As a consequence, net growth in the dilution experiments increased from around $0 \mathrm{~d}^{-1}$ up to $0.13 \mathrm{~d}^{-1}$ in the last days of the experiment, $35 \mathrm{~d}$ after the initial iron fertilization. This pattern did not reflect the dynamics of net phytoplankton accumulation in the fertilized patch, which increased until Days 24 to 27 and decreased thereafter. The difference between experimental and natural phytoplankton net growth is the biomass that escapes microzooplankton grazing and does not accumulate in the surface mixed layer, i.e. the biomass that went to higher trophic levels plus that exported out of the mixed layer. It increased throughout EIFEX and suggests a shift from a predominantly recycling system towards a more exporting one.
\end{abstract}

KEY WORDS: Microzooplankton grazing · Iron fertilization $\cdot \mathrm{C}$ export $\cdot$ Photoacclimation $\cdot$ HPLC pigments $\cdot$ Flow cytometry $\cdot$ Dilution experiments $\cdot$ Top-down control

Resale or republication not permitted without written consent of the publisher

\section{INTRODUCTION}

Mesoscale iron (Fe) fertilization experiments have demonstrated that phytoplankton is limited by $\mathrm{Fe}$ availability in high nitrate-low chlorophyll (HNLC) areas (Martin et al. 1994, de Baar et al. 2005, Boyd et al. 2007). Based on the contemporary understanding of the biological carbon pump, it can be deduced that phytoplankton blooms induced by $\mathrm{Fe}$ fertilization could produce a subsequent sequestration of fixed atmospheric carbon into the deep ocean. However, recent experiments have revealed the importance of initial conditions in the development of the bloom and possibly the fate of the organic matter (Coale et al. 2004, Peloquin et al. 2011, Martin et al. 2013). In particular, silicic acid concentrations may set an upper 
limit to the biomass of silica-shelled diatoms, a group that is considered highly efficient in exporting organic matter (Le Quéré et al. 2005). The Subarctic Pacific Iron Experiment for Ecosystem Dynamics Study (SEEDS) II project constitutes a notable exception because there was a muted response to Fe addition despite high silicic acid concentrations. This lack of diatom increase was attributed to high grazing pressure of mesozooplankton (Tsuda et al. 2007), although a complementary explanation is the absence of certain siderophores produced by some bacteria that prevented the uptake of Fe by diatoms (Wells et al. 2009).

Despite this new knowledge generated by largescale $\mathrm{Fe}$ fertilization experiments, the fate of the newly formed organic matter has remained elusive. Recently, Smetacek et al. (2012) reported a significant deep carbon export during the European Iron Fertilization Experiment (EIFEX). It has become clear that the initial environment largely determines the evolution of plankton communities, which in turn determine the fate of organic matter formed (Smetacek et al. 2004). The response of microzooplankton, responsible for most of the intake of primary production (Calbet \& Landry 2004), has followed somewhat different patterns in the experiments that have reported the evolution of phyto- and microzooplankton. In the IronEx II Fe fertilization experiment in the equatorial Pacific, the Southern Ocean Iron Release Experiment (SOIREE) and SEEDS I, microzooplankton biomass lagged the increase of phytoplankton, and only several weeks later, grazing rates by microzooplankton matched phytoplankton growth (Landry et al. 2000, Hall \& Safi 2001, Saito et al. 2005). This matching occurred because predation rates increased along with the abundance of microzooplankton, not because phytoplankton growth rates decreased. Apparently, phytoplankton did not undergo any kind of severe limitation. The matching coincided with the arrest in the increase of phytoplankton biomass, suggesting a control of some phytoplankton blooms (small species in the case of IronEx II) by microzooplankton. Dissimilar from this response, there was an alternation of microzooplankton groups in the in situ Fe enrichment experiment EisenEx, which resulted in a doubling of total phytoplankton biomass in the 3 wk experiment (Assmy et al. 2007). Grazing rates increased, but phytoplankton growth rates increased more, resulting in a decline in the control of phytoplankton by microzooplankton (Henjes et al. 2007).

EIFEX used the same technique employed during EisenEx (Gervais et al. 2002), but the sampling period was extended from 21 to $36 \mathrm{~d}$. The aim was to study the structure and dynamics of an Fe-induced bloom in the Southern Ocean for a longer period. The hypothesis that during this period the bloom's demise and the fate of the organic matter formed would be revealed has been confirmed (Smetacek et al. 2012). Because an important path of the fate of primary production is grazing by microzooplankton (Calbet \& Landry 2004) even in the presence of diatoms (Strom et al. 2001, Sherr \& Sherr 2007), our goal was to quantify the importance of this grazing during the long EIFEX experiment and its consequences.

\section{MATERIALS AND METHODS}

\section{Fe fertilization}

Altimetry data were used to search for a suitable cyclonic eddy within HNLC waters typical of the southern side of the polar front. The chosen eddy was located at $49^{\circ} 20^{\prime} \mathrm{S}, 2^{\circ} 15^{\prime} \mathrm{E}$. The first fertilization took place on 12 February 2004. The R/V 'Polarstern' steamed at $8 \mathrm{~km} \mathrm{~h}^{-1}$ on an outward spiralling track while delivering a slightly acidic solution of ferrous sulphate. The spiral measured $250 \mathrm{~km}$ in length with the 'circles' separated by $1 \mathrm{~km}$. It covered a circular area $14 \mathrm{~km}$ in diameter and $167 \mathrm{~km}^{2}$ in area (Smetacek et al. 2012). Initial concentrations of nitrate, nitrite, phosphate, silicic acid, ammonium and $\mathrm{Fe}$ in the upper $40 \mathrm{~m}$ were 25, 0.19, 1.8, 19 and $0.63 \mu \mathrm{mol} \mathrm{l} \mathrm{l}^{-1}$ and $0.2 \mathrm{nmol} \mathrm{l}^{-1}$, respectively. The first addition yielded Fe concentrations of about $1.5 \mathrm{nmol}$ $\mathrm{l}^{-1}$ in the $100 \mathrm{~m}$ surface mixed layer. On Day 13 after the first fertilization, a second fertilization took place,

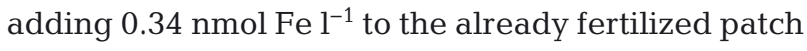
(Smetacek et al. 2012). The day of the first fertilization was considered Day 0 of the experiment. Sampling started $1 \mathrm{~d}$ before (Day -01) and ended $35 \mathrm{~d}$ later. Details on the sampling in the fertilized patch can be found in Smetacek et al. (2012).

\section{Dilution experiments}

We performed dilution experiments to simultaneously quantify phytoplankton growth and mortality rates (Landry \& Hassett 1982). Mortality is attributed mostly to microzooplankton. The contribution of mesozooplankton to the grazing rates estimated from our dilution experiments should be almost negligible. We sampled with Niskin bottles, which undersample mesozooplankton (Harris et al. 2000), and filter inspection of the filtered experimental bottles very seldom showed the presence of a single copepod at 
most. Because of the design of the experiments, mortality due to viruses could not be estimated and is reflected as lower phytoplankton growth rates. Incubations were performed on deck. Irradiance was measured inside the incubators throughout the development of the bloom and the screening adjusted to the irradiance level at $20 \mathrm{~m}$ depth (origin of the incubated sample), which was around $20 \%$ of the incident irradiance at the beginning of the cruise. On Day 25, an additional layer of screen reduced light to $15 \%$ of incident irradiance after observing photoacclimation to excess light in the incubated phytoplankton (see below). Temperature was regulated with surface seawater, which arrived at the incubator with $\sim 1^{\circ} \mathrm{C}$ increase relative to in situ $\left(4\right.$ to $\left.4.5^{\circ} \mathrm{C}\right)$. The initial water for the experiments was taken from $20 \mathrm{~m}$ depth in an attempt to avoid Fe contamination by the ship. The experiments lasted $48 \mathrm{~h}$, except the experiment on Day 32 that lasted $24 \mathrm{~h}$ (Table 1).

For the experiments, filtered seawater was prepared from a first CTD cast from $20 \mathrm{~m}$ depth by directly filtering the contents of the Niskin bottles by gravity through a $0.2 \mu \mathrm{m}$ pore size Suporcap cartridge (Pall-Gelman) previously cleaned with $\mathrm{HCl}$. The first 21 , at least, were discarded. The water from a second CTD cast from $20 \mathrm{~m}$ depth was used for setting up the experiment. The filtered seawater was used to obtain a dilution series of $10,20,30,40,50$ and $60 \%$ of whole seawater in 21 polycarbonate bottles (Table 1). Nutrients for K medium (Keller et al. 1987) were added to these diluted bottles and to 3 additional bottles containing whole seawater. The added nutrients were $\mathrm{NaNO}_{3}\left(5 \mu \mathrm{mol} \mathrm{l} l^{-1}\right), \mathrm{Na}_{2} \mathrm{HPO}_{4}\left(0.4 \mu \mathrm{mol} l^{-1}\right), \mathrm{Na}_{2} \mathrm{SiO}_{4}$ $\left(10 \mu \mathrm{mol} \mathrm{l} \mathrm{l}^{-1}\right), \mathrm{NH}_{4} \mathrm{Cl}\left(0.5 \mu \mathrm{mol} \mathrm{l}^{-1}\right)$, glucose $(1 \mu \mathrm{mol}$ $\left.\mathrm{l}^{-1}\right), \mathrm{FeCl}\left(29 \mathrm{nmol} \mathrm{l}^{-1}\right), \mathrm{MnSO}_{4}\left(2.2 \mathrm{nmol} \mathrm{l}^{-1}\right)$ and $\mathrm{ZnSO}_{4}\left(0.2 \mathrm{nmol} \mathrm{l}^{-1}\right)$. Thus the initial nutrient condition of the incubations was the sum of the ambient and the added nutrient concentrations.

\section{Biomass estimates}

For each incubation, initial and final pigment concentrations and cell optical characteristics and abundances were measured with HPLC and flow cytometry, respectively. For HPLC pigment analysis, a maximum of 21 were filtered through glass fiber filters (Whatman GF/F) with positive pressure $(<0.3 \mathrm{~atm})$ in a cold chamber at $5^{\circ} \mathrm{C}$. After filtration, filters were folded, blotted dry with absorbent paper, wrapped in aluminum foil and frozen and stored at $-80^{\circ} \mathrm{C}$. HPLC analysis was performed following the method of Zapata et al. (2000) as modified by Latasa et al. (2001). For flow cytometry analysis, the samples were run fresh in a CytoSense flow cytometer (model CytoBuoy) after remaining covered in the dark for 30 min to normalize short-term photoacclimation processes. No reliable cell concentrations could be obtained because of some clogging problems, and only red fluorescence (herein FLR) and forward scatter (herein FWS) will be presented.

Phytoplankton and microzooplankton (aloricate ciliates, thecate and athecate dinoflagellates) were sampled from a Sea-Bird 911plus CTD cast at 6 and 3 discrete depths, respectively, within the upper $100 \mathrm{~m}$ of the water column. Inventory of loricate ciliates (tintinnids) was made from samples collected at 8 to 15 discrete depths from a separate CTD cast down to depths of up to $550 \mathrm{~m}$ by gently concentrating 12 to 241 of seawater on a $20 \mu \mathrm{m}$ gauze. Microzooplankton larger or smaller than $60 \mu \mathrm{m}$ is referred to as large or small microzooplankton. The actual size range of small microzooplankton was between 5 and $60 \mu \mathrm{m}$ because of the technical limitation of optical microscopy for smaller sizes. For better comparison with dilution experiments, only the field data from $20 \mathrm{~m}$ depth are considered in this study. Unfortunately, sampling for biomass and dilution experiments could

Table 1. Dilution experiments performed during EIFEX. Exp and Day represent experiment number and day after first fertilization. Station indicates station and CTD cast; $T_{0}$ and Day $y_{0}$ and $T_{\mathrm{f}}$ and Day $\mathrm{y}_{\mathrm{f}}$ indicate initial and final time and day of the experiments, respectively. $E=$ total irradiance dosage at the surface in mol quanta $\mathrm{m}^{-2}$ during each experiment; $k_{\mathrm{d}}=$ the diffuse attenuation coefficient of downwelling irradiance in $\mathrm{m}^{-1}$ (in brackets, the station where the measurement was made); Phi $=$ photoacclimation index $;$ nd $=$ not determined

\begin{tabular}{|c|c|c|c|c|c|c|c|c|c|}
\hline Exp & Day & Station & $T_{0}$ & Day $_{0}$ & $T_{\mathrm{f}}$ & $\operatorname{Day}_{f}$ & $E$ & $k_{\mathrm{d}}$ & Phi \\
\hline 02 & -01 & 424-17. CTD IV & 03:30 & $12 \mathrm{Feb}$ & 03:30 & $14 \mathrm{Feb}$ & 48 & 0.078 (st426) & 1.61 \\
\hline 05 & 09 & 508-16. CTD IV & $18: 30$ & 22 Feb & $17: 00$ & 24 Feb & 45 & 0.104 & 0.93 \\
\hline 08 & 14 & 513-9. CTD III & $23: 40$ & 27 Feb & 01:00 & 01 Mar & 55 & 0.111 (st516) & 0.91 \\
\hline 12 & 21 & 544-5. CTD III & $18: 30$ & 05 Mar & $18: 30$ & 07 Mar & 22 & 0.125 & 0.67 \\
\hline 15 & 27 & 553-9. CTD III & $23: 00$ & 11 Mar & $23: 00$ & 13 Mar & 40 & 0.135 (st558) & $0.84^{\mathrm{a}}$ \\
\hline 18 & 32 & 580-8. CTD III & 07:00 & $16 \mathrm{Mar}$ & 07:15 & $17 \mathrm{Mar}$ & 10 & 0.119 & 0.84 \\
\hline 21 & 35 & 591-5. CTD III & $10: 00$ & 19 Mar & $08: 30$ & 21 Mar & 27 & nd & 0.90 \\
\hline
\end{tabular}


not be performed from the same cast. Thus, the chl $a$ :C ratio from the closest biomass cast was used to estimate phytoplankton carbon (Phyto-C) in the experiments from the initial chl a concentration. For microzooplankton, concentrations on the experimental days were derived by interpolation between temporally adjacent samples.

Diatoms and other protists with robust cell walls were enumerated in water samples fixed with hexamethylenetetramine-buffered formaldehyde solution at a final concentration of $2 \%$, whereas unarmored species (athecate dinoflagellates, aloricate ciliates and flagellates) were counted in water samples preserved with acidic Lugol's iodine solution at a final concentration of $5 \%$. Cells were identified and enumerated using inverted light and epifluorescence microscopy (Axiovert 25 and Axiovert 135, Zeiss) as described by Throndsen (1995). Subsamples were settled in $50 \mathrm{ml}$ sedimentation chambers (Hydrobios) for $48 \mathrm{~h}$. Organisms were counted at magnifications of 200 to $640 \times$ according to the size of the organisms examined. Each sample was examined until at least 500 cells had been counted. For phytoplankton, the average cell size of each species was used to calculate the biovolume from equivalent geometrical shapes (Hillebrand et al. 1999) and the biovolume converted to cellular carbon content through carbon conversion equations (Menden-Deuer \& Lessard 2000). For microzooplankton, the sizes of species were measured and their biovolume calculated from equivalent geometrical shapes (Edler 1979). Biovolumes were calculated from measurements on at least 30 to 40 randomly chosen cells of $20 \mu \mathrm{m}$ size classes. Cell volume was converted to cellular carbon content using the following carbon-to-volume relationships (Menden-Deuer \& Lessard 2000): $\mathrm{C} \mathrm{cell}^{-1}=$ $0.444 \times V^{0.864}$ for heterotrophic dinoflagellates, C cell $^{-1}=0.230 \times V^{0.984}$ for aloricate ciliates, $\mathrm{C} \mathrm{cell}{ }^{-1}=$ $0.679 \times V^{0.841}$ for tintinnid ciliates and $\mathrm{C} \mathrm{cell}^{-1}=0.216$ $\times V^{0.939}$ for the remaining protozoan taxa, with $V$ representing total cell volume $\left(\mu \mathrm{m}^{3}\right)$ and $\mathrm{C}$ describing cellular carbon content (pg).

\section{Irradiance and photoacclimation}

Incident photosynthetically available radiation (PAR) was measured every 5 min with a shipmounted quantum sensor (LI-192, LI-COR) connected to a data logger (LI-1000, LI-COR). It agreed well with incident PAR $\left(\mathrm{r}^{2}=0.91\right)$ calculated from shipbased global radiation measurements. The diffuse attenuation coefficient of downwelling PAR irradi- ance $\left(k_{\mathrm{d}}\right)$ was determined for the surface mixed layer by linear regression of log-transformed PAR measurements over depths, using measurements of a spherical PAR sensor (QSP-2200, Biospherical Instruments) connected to the ship's CTD.

To check for a possible photoacclimation of phytoplankton cells during incubations, their FLR:FWS ratio was measured with the flow cytometer. FLR is a proxy for pigment (chl a) concentration, and FWS is a proxy for cell size or carbon (Gutiérrez-Rodríguez et al. 2010) and was confirmed by the positive correlation (Pearson's $r=0.82, \mathrm{p}=0.023, \mathrm{n}=7$ ) between the FLR:FWS and chl a:Phyto-C (derived from counts, see above) ratios. The FLR:FWS ratio was obtained for cells at the beginning and end of each incubation, and a photoacclimation index (Phi) was estimated to assess unbalanced synthesis or dilution of pigments (Gutiérrez-Rodríguez et al. 2010):

$$
\text { Phi }=(\text { FLR:FWS })_{\text {final }} /(\text { FLR:FWS })_{\text {initial }}
$$

Phi (Table 1) was used to calculate growth rates (see below). There were no flow cytometry data for Day 27, and we applied the Phi value of Day 32. The same correction value was applied for fucoxanthin and 19'-hexanoyloxyfucoxanthin because it has been shown that light-harvesting pigments co-vary with chl a (Goericke \& Montoya 1998). The flow cytometer size range considered was 2 to $200 \mu \mathrm{m}$.

\section{Rate estimations}

Intrinsic growth $(\mu)$ was estimated from the $y$-intercept of the linear regression of the apparent growth rates in the 6 diluted incubations (10 to $60 \%$ of whole seawater). Apparent growth rate $(k)$ in each bottle was estimated from the following equation:

$$
k=1 / t \ln \left[N_{\mathrm{f}} \times\left(N_{0} \times D \times \mathrm{Phi}\right)^{-1}\right]
$$

where $N_{0}$ and $N_{\mathrm{f}}$ are initial and final pigment concentrations, $D$ the dilution, Phi is the photoacclimation index (see above) and $t$ is the period of incubation (d). The use of a regression of the most diluted samples to estimate $\mu$ should minimize problems from non-linear responses of grazing with dilution (Gallegos 1989, Redden et al. 2002, Moigis 2006) because (1) possible saturation problems taking place in the less diluted samples are avoided, (2) cascading effects affecting microzooplankton are reduced in the most diluted treatments and (3) threshold problems that might occur in very diluted samples can be detected. Threshold for microzooplankton feeding seems rare in natural samples 


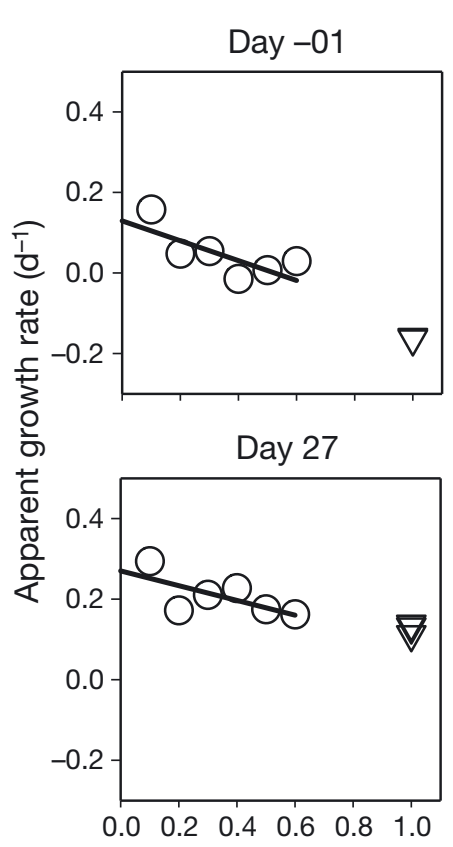

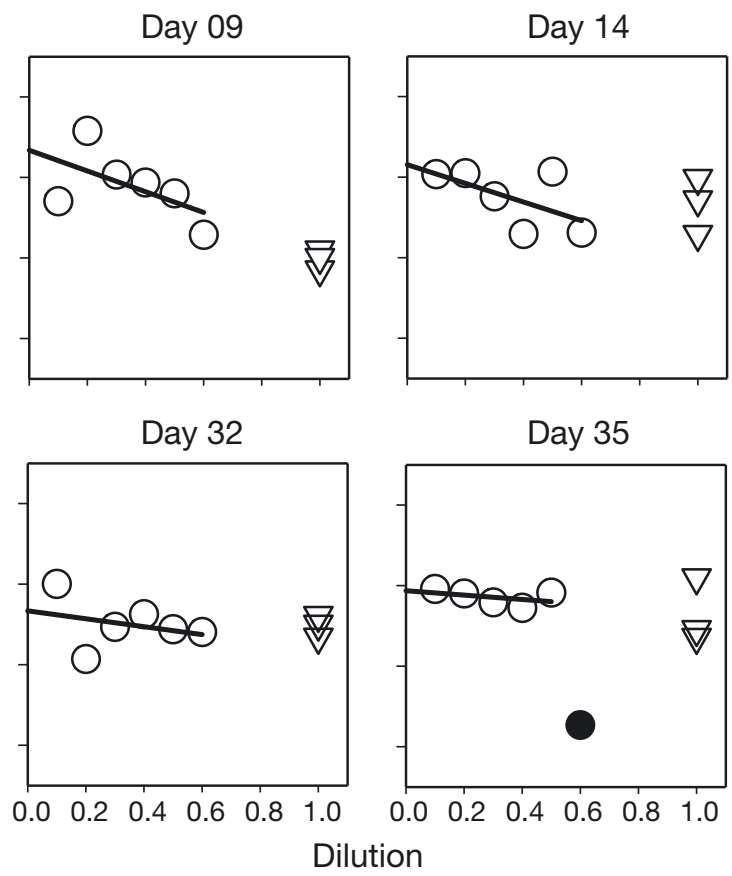

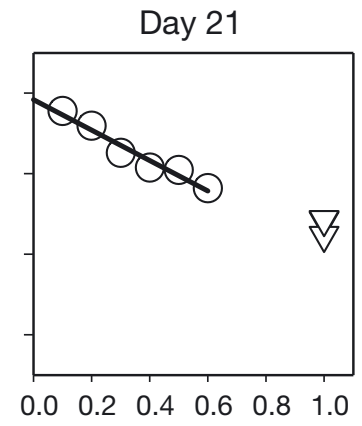

Fig. 1. Results from the 7 dilution experiments performed in the fertilized patch. Apparent growth rates are estimated from changes in chl a after correction for photoacclimation during the experiment (see 'Materials and methods'). The whole water treatment (dilution $=1$, inverted triangles) is not included in the estimation of the linear regression (see 'Materials and methods'). The 0.6 dilution on Day 35 (filled circle) was excluded from the calculations

\section{RESULTS}

Seven experiments were performed on deck with samples from the fertilized patch (Fig. 1). Reliable estimates were obtained only for diatoms and prymnesiophytes from their pigment markers fucoxanthin and 19'-hexanoyloxyfucoxanthin, respectively. The low concentration of the pigment markers of dinoflagellates (peridinin) and pelagophytes (19'-butanoyloxyfucoxanthin) precluded their accurate quantification in most of the diluted bottles.

The CTD profiles of temperature and salinity showed that the boundary of the mixed layer - the zone of relatively homogeneous water formed by the history of mixing - was located at ca. $100 \mathrm{~m}$, with an active mixing layer - the zone in which mixing is occurring - from 35 to $60 \mathrm{~m}$ depth (Cisewski et al. 2008), which included our 20 m sampling depth.

\section{Biomass}

Fe fertilization induced a remarkable increase in phytoplankton biomass (chl a, Table 2), principally from diatoms (Hoffmann et al. 2006, Assmy et al. 2013). The following 10 species (8 of which are diatoms), ranked according to their relative contribution, accounted for $62 \%$ of total Phyto-C standing stocks inside the fertilized patch: the diatoms Fragilariopsis kerguelensis and Dactyliosolen antarcticus; the prymnesiophyte Phaeocystis antarctica (domisive experiments. 
Table 2. Initial biomass $\left(\mathrm{mg} \mathrm{m}^{-3}\right)$ and rates $\left(\mathrm{d}^{-1}\right)$ of intrinsic growth $(\mu)$, grazing $(g)$ and net growth $\left(\mu_{\text {net }}\right)$ for phytoplankton (chl a), diatoms (fucoxanthin) and prymnesiophytes (19'-hexanoyloxyfucoxanthin) inside the fertilized patch. Phytoplankton carbon biomass (Phyto-C) was derived from microscopy cell counts and biovolume calculation. The slope, coefficient of determination $\left(\mathrm{r}^{2}\right)$ and $\mathrm{p}$-value of the regression of rates against time are presented in the last rows

\begin{tabular}{|c|c|c|c|c|c|c|c|c|c|c|c|c|c|}
\hline \multirow[b]{2}{*}{ Day } & \multicolumn{4}{|c|}{$-\mathrm{Chl} \mathrm{a}-$} & \multicolumn{4}{|c|}{-Fucoxanthin } & \multicolumn{4}{|c|}{ 19'-Hexanoyloxyfucoxanthin } & \multirow{2}{*}{$\begin{array}{l}\text { Phyto-C } \\
\mathrm{mg} \mathrm{C} \mathrm{m}^{-3}\end{array}$} \\
\hline & $\mu$ & $g$ & $\mu_{\text {net }}$ & $\mathrm{mg} \mathrm{m}^{-3}$ & $\mu$ & $g$ & $\mu_{\text {net }}$ & $\mathrm{mg} \mathrm{m}^{-3}$ & $\mu$ & $g$ & $\mu_{\text {net }}$ & $\mathrm{mg} \mathrm{m}^{-3}$ & \\
\hline-01 & 0.13 & 0.29 & -0.16 & 0.70 & 0.18 & 0.30 & -0.13 & 0.17 & -0.10 & 0.25 & -0.35 & 0.18 & 30.9 \\
\hline 09 & 0.27 & 0.27 & 0.00 & 1.51 & 0.20 & 0.14 & 0.06 & 0.42 & 0.23 & 0.33 & -0.10 & 0.19 & 42.3 \\
\hline 14 & 0.23 & 0.13 & 0.10 & 2.13 & 0.20 & 0.15 & 0.05 & 0.67 & 0.19 & 0.11 & 0.08 & 0.16 & $59.5^{\mathrm{a}}$ \\
\hline 21 & 0.38 & 0.31 & 0.07 & 2.75 & 0.44 & 0.32 & 0.11 & 0.85 & 0.34 & 0.18 & 0.16 & 0.18 & $77.8^{\mathrm{b}}$ \\
\hline 27 & 0.27 & 0.14 & 0.13 & 3.16 & 0.25 & 0.10 & 0.15 & 1.11 & 0.08 & 0.05 & 0.04 & 0.19 & 83.2 \\
\hline 32 & 0.13 & 0.04 & 0.10 & 3.08 & 0.18 & 0.05 & 0.12 & 1.07 & 0.13 & 0.00 & 0.13 & 0.19 & 65.1 \\
\hline 35 & 0.19 & 0.06 & 0.13 & 2.56 & 0.27 & 0.16 & 0.11 & 0.94 & 0.14 & 0.01 & 0.13 & 0.14 & $61.9^{c}$ \\
\hline Avg. & 0.23 & 0.18 & 0.05 & & 0.24 & 0.18 & 0.07 & & 0.14 & 0.13 & 0.01 & & \\
\hline $\mathrm{SD}$ & 0.09 & 0.11 & 0.10 & & 0.09 & 0.10 & 0.09 & & 0.14 & 0.13 & 0.18 & & \\
\hline Slope & 0.000 & -0.007 & 0.007 & 0.062 & 0.002 & -0.004 & 0.006 & 0.025 & 0.004 & -0.008 & 0.012 & -0.000 & 1.06 \\
\hline $\mathrm{r}^{2}$ & 0.002 & 0.57 & 0.75 & 0.81 & 0.08 & 0.29 & 0.74 & 0.88 & 0.11 & 0.75 & 0.71 & 0.08 & 0.56 \\
\hline $\mathrm{p}$ & 0.92 & 0.048 & 0.01 & 0.006 & 0.45 & 0.21 & 0.01 & 0.002 & 0.65 & 0.01 & 0.02 & 0.54 & 0.053 \\
\hline
\end{tabular}

nated by solitary cells); the diatoms Thalassiothrix antarctica, Chaetoceros dichaeta and Corethron pennatum; the dinoflagellate Prorocentrum spp.; and the diatoms Rhizosolenia chunii, Guinardia cylindrus and Corethron inerme. Phyto-C followed a pattern similar to chl a (Table 2), increasing in a linear fashion during the first part of the cruise from $31 \mathrm{mg} \mathrm{C}$ $\mathrm{m}^{-3}$ at Day -01 to $83 \mathrm{mg} \mathrm{C} \mathrm{m}{ }^{-3}$ at Day 27 and decreasing afterwards. Microprotozooplankton biomass, however, remained relatively stable $(7.7 \pm$ $1.1 \mathrm{mg} \mathrm{C} \mathrm{m}^{-3}$ ). There was an important shift in populations during the cruise, with large microprotozooplankton $(>60 \mu \mathrm{m})$ significantly increasing their con- tribution to microprotozooplankton biomass from 26 to $53 \%$, i.e. 2.2 to $3.7 \mathrm{mg} \mathrm{C} \mathrm{m}^{-3}$ (Table 3, linear regression, $r^{2}=0.54, p=0.02, n=9$ ). Within this size class, biomass of tintinnids and thecate dinoflagellates increased significantly $\left(r^{2}=0.72, p=0.004\right.$, and $\mathrm{r}^{2}=0.74, \mathrm{p}=0.03$, respectively, $\mathrm{n}=9$ for both), that of aloricate ciliates decreased significantly $\left(\mathrm{r}^{2}=0.47, \mathrm{p}\right.$ $=0.04, \mathrm{n}=9$ ) and that of athecate dinoflagellates did not change $(\mathrm{p}=0.85$, Table 3$)$. Protoperidinium spp. and Stenosomella spp. experienced the strongest increases through EIFEX. On average, large athecate dinoflagellates, large thecate dinoflagellates, large aloricate ciliates and tintinnids contributed 4, 12, 14

Table 3. Carbon biomass $\left(\mathrm{mg} \mathrm{m}^{-3}\right.$ ) of microprotozooplankton groups during EIFEX at 20 to $25 \mathrm{~m}$ depth. The slope, coefficient of determination $\left(\mathrm{r}^{2}\right)$ and $\mathrm{p}$-value of the regression of biomass against time are presented in the last rows

\begin{tabular}{|c|c|c|c|c|c|c|c|c|c|}
\hline \multirow[t]{2}{*}{ Day } & \multicolumn{2}{|c|}{ Athecate dinoflagellates } & \multicolumn{2}{|c|}{ Thecate dinoflagellates } & \multicolumn{2}{|c|}{ Aloricate ciliates } & \multirow{2}{*}{$\begin{array}{l}\text { Tintinnids } \\
>60 \mu \mathrm{m}\end{array}$} & \multicolumn{2}{|c|}{ Total } \\
\hline & $<60 \mu \mathrm{m}$ & $>60 \mu \mathrm{m}$ & $<60 \mu \mathrm{m}$ & $>60 \mu \mathrm{m}$ & $<60 \mu \mathrm{m}$ & $>60 \mu \mathrm{m}$ & & $<60 \mu \mathrm{m}$ & $>60 \mu \mathrm{m}$ \\
\hline-01 & 2.65 & 0.45 & 1.67 & 0.13 & 1.89 & 1.53 & 0.10 & 6.24 & 2.21 \\
\hline 05 & 2.63 & 0.23 & 1.48 & 0.13 & 2.17 & 2.04 & 0.23 & 6.29 & 2.62 \\
\hline 09 & 1.63 & 0.23 & 1.19 & 0.79 & 2.69 & 1.02 & 0.33 & 5.55 & 2.38 \\
\hline 19 & 2.19 & 0.28 & 0.80 & 0.40 & 1.78 & 1.53 & 0.77 & 4.78 & 2.98 \\
\hline 24 & 1.60 & 0.36 & 1.92 & 1.45 & 1.54 & 0.51 & 1.11 & 5.09 & 3.43 \\
\hline 28 & 1.79 & 0.35 & 0.98 & 1.19 & 1.56 & 0.89 & 1.32 & 4.35 & 3.76 \\
\hline 30 & 0.80 & 0.00 & 0.84 & 1.19 & 0.98 & 0.51 & 0.71 & 2.64 & 2.41 \\
\hline 32 & 1.08 & 0.68 & 0.77 & 1.06 & 1.83 & 1.27 & 1.33 & 3.69 & 4.34 \\
\hline 35 & 0.83 & 0.15 & 0.70 & 1.72 & 1.66 & 0.64 & 1.16 & 3.20 & 3.67 \\
\hline Slope & -0.048 & -0.001 & -0.022 & 0.038 & -0.023 & -0.028 & 0.032 & -0.092 & 0.043 \\
\hline$r^{2}$ & 0.75 & 0.005 & 0.39 & 0.74 & 0.39 & 0.47 & 0.72 & 0.84 & 0.54 \\
\hline $\mathrm{p}$ & 0.025 & 0.85 & 0.07 & 0.03 & 0.07 & 0.04 & $<0.01$ & $<0.01$ & 0.02 \\
\hline
\end{tabular}




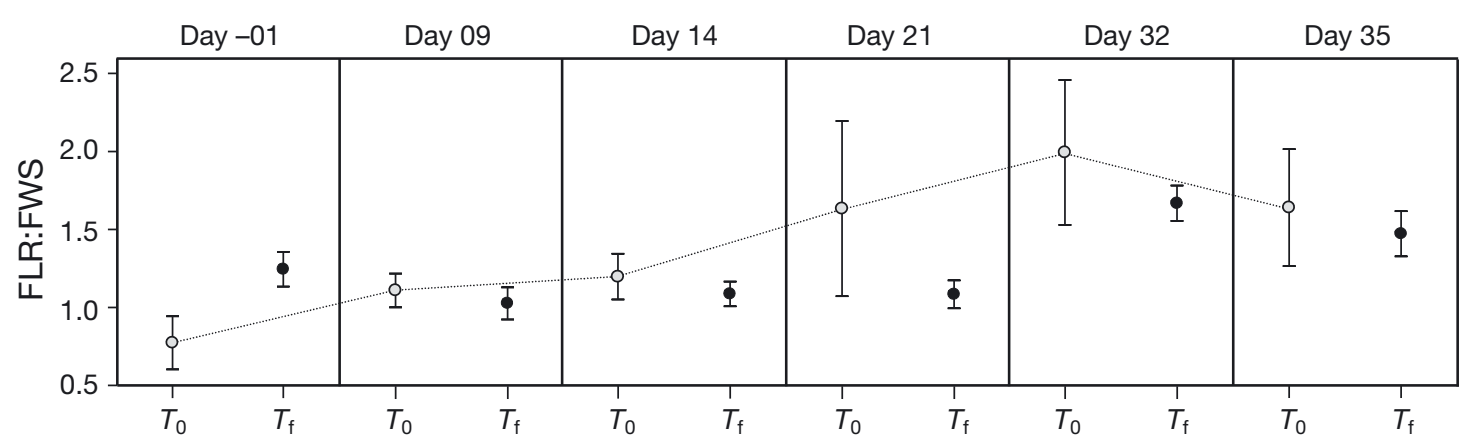

Fig. 2. Time evolution of the red fluorescence:forward scatter (FLR:FWS) ratio (arbitrary units) at the beginning $\left(T_{0}\right.$, grey circles) and end $\left(T_{\mathrm{f}}\right.$, black circles) of each dilution experiment. The evolution of the in situ samples ( $\left.T_{0}\right)$ is connected with the dotted line. This ratio is a proxy for the chl a: C ratio in the cells. Bars indicate mean $\pm 95 \%$ CI. No flow cytometry data were available for Day 27

and $10 \%$ to the total microprotozooplankton biomass, respectively (Table 3). In contrast to the large fraction, the biomass of small microprotozooplankton $(<60 \mu \mathrm{m})$ decreased significantly with time from 6.2 to $3.2 \mathrm{mg} \mathrm{C} \mathrm{m}^{-3}$ (Table 3, linear regression, $\mathrm{r}^{2}=0.84$, $\mathrm{p}<0.001, \mathrm{n}=9$ ). The biomass decrease was statistically significant for small athecate dinoflagellates $\left(r^{2}=0.75, p=0.02, n=9\right)$ and non-significant for small thecate dinoflagellates and small aloricate ciliates ( $p=0.07$ for both, Table 3$)$. On average, small organisms constituted $60 \%$ of microprotozooplankton biomass, with small aloricate ciliates, small athecate dinoflagellates and small thecate dinoflagellates contributing 23, 22 and $15 \%$, respectively (Table 3 ).

\section{Irradiance and photoacclimation}

Incident irradiance $(E)$ during the incubation, the diffuse attenuation coefficient of downwelling irradiance $\left(k_{\mathrm{d}}\right)$ and the photoacclimation index (Phi) are shown in Table 1. Irradiance inside the incubators was attenuated to $20 \%$ of PAR until Day 25 and $15 \%$ thereafter. Both irradiance dosage in the incubators and $k_{\mathrm{d}}$ decreased with time (linear regression, $\mathrm{r}^{2}=$ 0.67, $\mathrm{p}=0.02$ for irradiance, $\mathrm{r}^{2}=0.78, \mathrm{p}=0.02$ for $k_{\mathrm{d}}$ ). The euphotic zone (1\% of surface irradiance) decreased from 60 to $\sim 35 \mathrm{~m}$ depth during the course of the Fe enrichment experiment, because of decreasing light availability in the $100 \mathrm{~m}$ mixed water column. Determination of the light history of a particle in a turbulent, mixed water column is a difficult and not well-resolved issue. Therefore, our approach was to estimate and correct the possible effects of different irradiance conditions between in situ and experimental incubations. With this goal, we examined the photoacclimation of individual cells. Two scales of photoacclimation should be distinguished here: (1) during the experimental incubation, because of potential changes between in situ light dose and that in the incubator; and (2) during the development of the bloom, with increasing biomass and decrease of underwater irradiance because of phytoplankton shelf shading. Photoacclimation for both types of processes was checked and corrected by the FLR:FWS ratio obtained from flow cytometry analysis of single cells. A calculation based on the light attenuation coefficients, which varied between 0.078 and $0.135 \mathrm{~m}^{-1}$ (Table 1), indicated that the average light availability in the $100 \mathrm{~m}$ mixed water column varied between 8 and $13 \%$ of the incident irradiance. This light level was found between 19 and $26 \mathrm{~m}$ depth, very close to our $20 \mathrm{~m}$ sampling depth, indicating that the $20 \mathrm{~m}$ depth level was a good choice for a representative sample of the whole mixed water column. Only during Day -01 was there a significant increase in the FLR:FWS ratio (a proxy for the chl a:C ratio, see 'Materials and methods') during the incubation (Fig. 2). In the rest of the experiments, cells decreased their FLR:FWS ratio although not significantly ( $t$-test, $\mathrm{p}>0.05$ for all experiments), hinting that they were receiving a slightly higher irradiance dose (15 to $20 \%$ ) than in situ (8 to $13 \%$ ) (Fig. 2). In situ FLR:FWS ratios increased during the development of the bloom and were correlated with $k_{\mathrm{d}}$ (Figs. $2 \& 3$ ). The decrease of irradiance available to phytoplankton in the mixed water column due to biomass buildup during the bloom and, especially, the enhancement of cellular chl a content after Fe fertilization likely contributed to the observed increase in pigment content per cell.

\section{Rates and balances}

Phytoplankton intrinsic growth rates did not show a linear trend with time (Table 2). Growth rates were low $\left(0.23 \pm 0.09 \mathrm{~d}^{-1}\right)$ and significantly higher $(\mathrm{p}<$ 


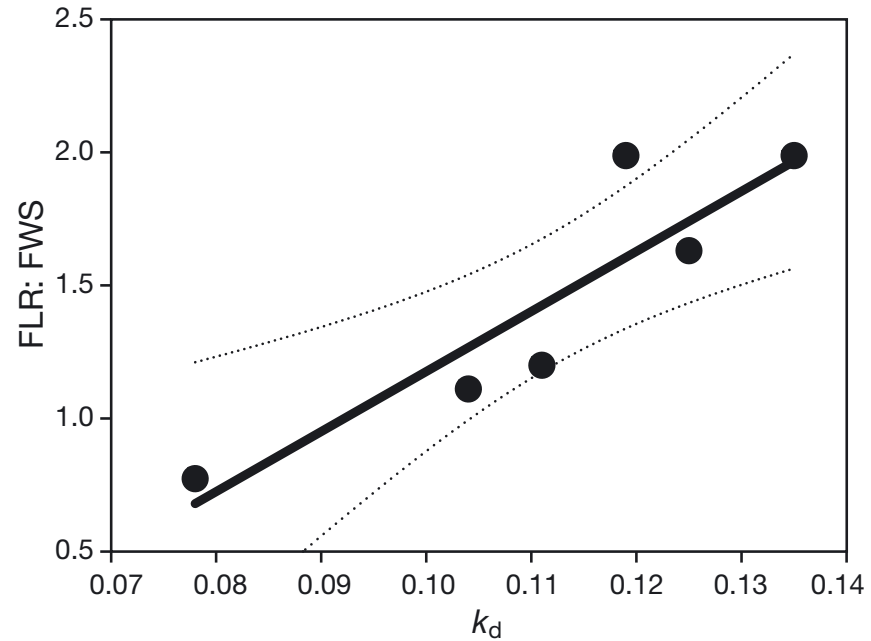

Fig. 3. Relationship between red fluorescence:forward scatter (FLR:FWS) ratio (arbitrary units) of the in situ samples and attenuation coefficient $k_{\mathrm{d}}\left(\mathrm{m}^{-1}\right)$. Dotted lines represent the $95 \% \pm$ confidence interval

0.05 , paired $t$-test $)$ for diatoms $\left(0.24 \pm 0.09 \mathrm{~d}^{-1}\right)$ than for prymnesiophytes $\left(0.14 \pm 0.14 \mathrm{~d}^{-1}\right)$. Grazing rates were low $\left(0.18 \pm 0.11 \mathrm{~d}^{-1}\right)$ and not statistically different between diatoms $\left(0.18 \pm 0.10 \mathrm{~d}^{-1}\right)$ and prymnesiophytes $\left(0.13 \pm 0.13 \mathrm{~d}^{-1}\right)$. Phytoplankton mortality $(g$ from chl $a$, Table 2) showed a significant decrease with time (linear regression, $g=0.31-0.0066 \times$ day, $\mathrm{r}^{2}=0.57, \mathrm{p}<0.05, \mathrm{n}=7$, Table 2). Grazing was positively correlated to small microzooplankton biomass (Fig. 4, Deming regression, $\mathrm{p}=0.02$, grazing rate $\mathrm{SD}$ $=0.04$, microprotozooplankton biomass $\mathrm{SD}=0.4, \mathrm{n}$ $=7$ ). As a result of this divergence between growth and grazing, net growth rates increased significantly with time (Table 2).

The amount of carbon synthesized per day increased with time and reached a value of $35 \mathrm{mg} \mathrm{C}$ $\mathrm{m}^{-3} \mathrm{~d}^{-1}$ during Days 21 to 27 , with a sharp decline afterwards (Fig. 5a). The amount of carbon consumed by microzooplankton reached a maximum of $24 \mathrm{mg} \mathrm{C} \mathrm{m}{ }^{-3} \mathrm{~d}^{-1}$ during the same period and also decreased strongly thereafter. Net production in our experiments reached a maximum of $12.5 \mathrm{mg} \mathrm{C} \mathrm{m}^{-3}$ $\mathrm{d}^{-1}$ during Days 27 to 32 (Fig. 5b). We assume that the negative values of net carbon synthesis estimated in the first part of EIFEX are due to experimental and sampling variability in a low-export environment during bloom buildup. The carbon produced during the $36 \mathrm{~d}$ of EIFEX in our 21 bottles was $636 \mathrm{mg} \mathrm{C} \mathrm{m}^{-3}$, and the amount consumed by microzooplankton was $440 \mathrm{mg} \mathrm{C} \mathrm{m}^{-3}$, which leaves $196 \mathrm{mg} \mathrm{C} \mathrm{m}{ }^{-3}$ for bloom buildup, mesozooplankton grazing and export.

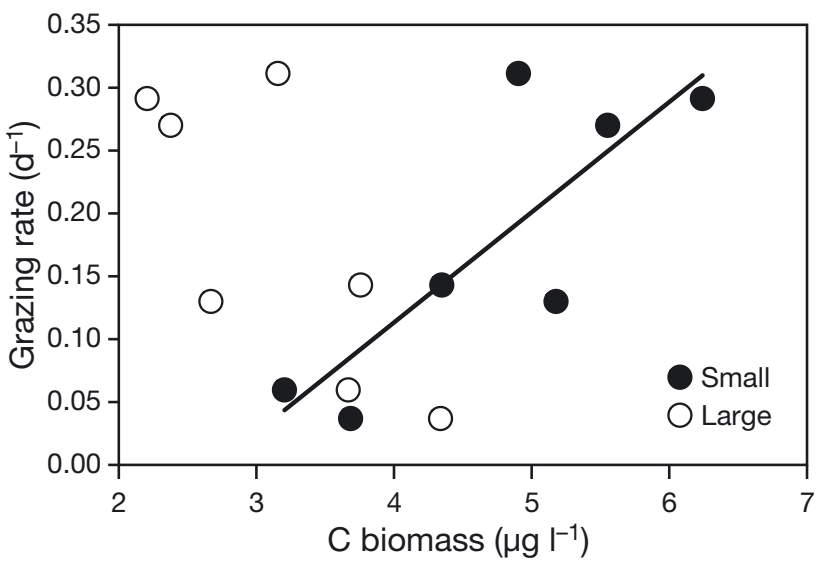

Fig. 4. Relationship (Deming regression) between carbon (C) biomass of small $(<60 \mu \mathrm{m})$ and large $(>60 \mu \mathrm{m})$ microprotozooplankton and grazing rate. Slope was statistically different from 0 for small microprotozooplankton $(p=0.02)$; $\mathrm{p}=0.051$ for large microprotozooplankton

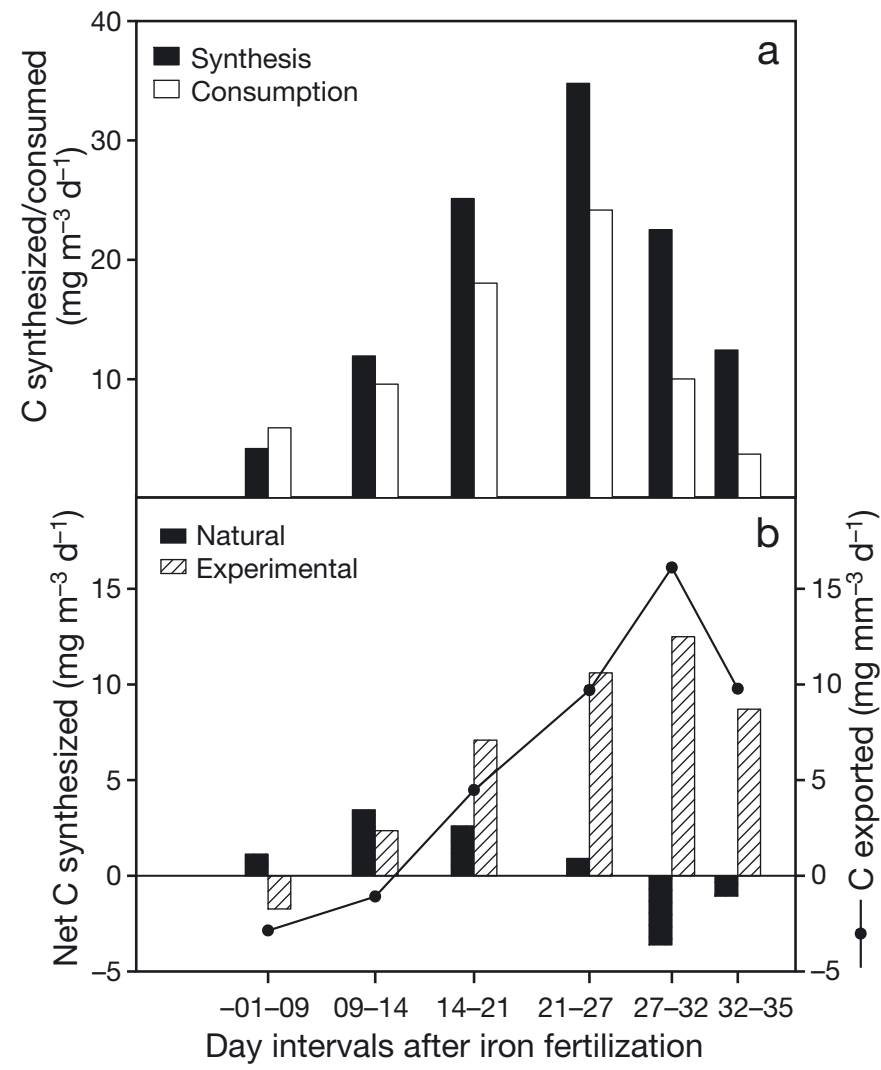

Fig. 5. (a) Synthesis and consumption and (b) experimental and natural net synthesis of phytoplankton carbon (C) per day for time intervals between dilution experiments. Natural net synthesis was obtained from the phytoplankton C evolution in the bloom as follows: Natural net synthesis $=\left(N_{n+1}\right.$ $\left.-N_{\mathrm{n}}\right)\left(t_{\mathrm{n}+1}-t_{\mathrm{n}}\right)^{-1}$, where $N$ is phytoplankton $\mathrm{C}$ concentration $\left(\mathrm{mg} \mathrm{m}^{-3}\right.$ ) and $t$ is time (d). C exported is the result of the subtraction of natural net synthesis from experimental net synthesis, i.e. the biomass that went to higher trophic levels plus that exported out of the mixed layer 


\section{DISCUSSION}

The sampling depth of the experiments was part of a mixed layer that extended down to $100 \mathrm{~m}$ (Cisewski et al. 2008) where nutrients, including Fe, were nonlimiting for phytoplankton growth during the EIFEX fertilization experiment (Smetacek et al. 2012). The extra addition of nutrients in the dilution treatments was therefore superfluous and should not distort the growth dynamics in the experiments. Fe addition resulted in a large phytoplankton bloom. Details on phytoplankton dynamics and composition can be found elsewhere (Hoffmann et al. 2006, Smetacek et al. 2012, Assmy et al. 2013). Briefly, diatoms were already the most abundant group before Fe fertilization. They were responsible for the main biomass increase, doubling their contribution in terms of carbon during the experiment. Phaeocystis, the dominant prymnesiophyte, came next in importance and was largely represented by solitary cells, but its contribution to chl a remained at $20 \%$ (Hoffmann et al. 2006).

Phytoplankton intrinsic growth rates remained rather low ( 0.13 to $0.38 \mathrm{~d}^{-1}$, average $=0.23 \mathrm{~d}^{-1}$, Table 2 ) but similar to the 0.22 to $0.33 \mathrm{~d}^{-1}$ rates obtained in a previous $\mathrm{Fe}$ fertilization experiment in the area (EisenEx, Henjes et al. 2007) or those reported by Landry et al. (2002) for the polar front area in February to March $\left(0.07\right.$ to $\left.0.28 \mathrm{~d}^{-1}\right)$. As expected, growth rates of diatoms were higher than those of prymnesiophytes and typical of Southern Ocean species (Timmermans et al. 2001). Light limitation induces an increase in cell pigment concentration and was investigated as a possible factor influencing phytoplankton growth and bloom demise. Chl a:C ratios increased more strongly immediately after Fe fertilization (Day -01, Table 2), probably because of Fe limitation alleviation, which allowed subsequent chl a synthesis (Boyd et al. 2001, Hoffmann et al. 2007). Growth rates were inversely correlated to chl $a$ :C ratio $(\mathrm{p}<0.05)$ in the fertilized patch, suggesting that irradiance was limiting intrinsic growth rates at $20 \mathrm{~m}$ depth. However, the similarity between the measured growth values and those reported from the literature in the area (Landry et al. 2002, Henjes et al. 2007) suggests that low irradiances were not the direct cause for the bloom demise.

Mortality rates of phytoplankton were comparable to growth rates (Table 2). We checked whether the estimated grazing rates were realistic based on protozooplankton abundances. Assuming that phytoplankton mortality in our experiments was only due to protozooplankton, we estimated clearance rates ranging from 5 to $39 \mathrm{ml} \mu \mathrm{g} \mathrm{C}^{-1} \mathrm{~d}^{-1}(22 \pm 14$, mean $\pm \mathrm{SD})$. The

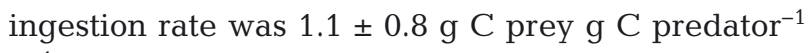
$\mathrm{d}^{-1}$. These rates appear high, i.e. they ingested more than their body weight per day. However, the relatively few studies presenting ingestion rates as a function of protozooplankton biomass show a considerable variability where our estimates fit in the middle part of the range. Some reports of ingestion rates in cold waters include values of $0.8 \mathrm{~g} \mathrm{C} \mathrm{g} \mathrm{C}$ dinoflagellate ${ }^{-1} \mathrm{~d}^{-1}$ in the Weddell Sea (Bjornsen \& Kuparinen 1991), $0.35 \mathrm{~g} \mathrm{C}$ phototrophic flagellates $\mathrm{g}$ $\mathrm{C}$ dinoflagellate ${ }^{-1} \mathrm{~h}^{-1}$ (equivalent to $8.4 \mathrm{~g} \mathrm{C} \mathrm{g} \mathrm{C}^{-1} \mathrm{~d}^{-1}$ ) in the Southern Ocean between $47^{\circ}$ and $60^{\circ} \mathrm{S}$ (Becquevort 1997), 0.2 to $0.8 \mathrm{~g} \mathrm{C}$ prey g C predator $^{-1}$ $\mathrm{d}^{-1}$ in a fjord (Archer et al. (2000) and $2.5 \mathrm{~g} \mathrm{C}$ prey g C predator $^{-1} \mathrm{~d}^{-1}$ in the Mediterranean in February at $6^{\circ} \mathrm{C}$ (Fonda-Umani \& Beran 2003). Therefore, we conclude that the measured grazing rates are realistic.

An explanation for the negative net growth rates at the initial stages of the Fe fertilization is the potential increase of microprotozooplankton grazers and grazing rates when mesozooplankton, which predate on protozooplankton (Stoecker \& Capuzzo 1990, Calbet and Saiz 2005), are excluded from our relatively small incubation bottles. In addition, Niskin bottles undersample mesozooplankton (Harris et al. 2000). Thus, the measured grazing rates should be regarded as a potential maximum herbivory. The most surprising result regarding grazing rates was the relatively high values at the beginning that matched growth rates and their decline towards the end of the cruise (Table 2). We argue that the observed dynamics are due to the initial conditions of EIFEX. A natural bloom, probably caused by aeolian $\mathrm{Fe}$ input (Cassar et al. 2007), was responsible for the high autotrophic biomass (especially diatoms), the high microprotozooplankton and mesozooplankton biomass (see Table 3 for microprotozooplankton, $2.4 \mathrm{~g} \mathrm{C}$ $\mathrm{m}^{-2}$ for mesozooplankton in the 0 to $400 \mathrm{~m}$ layer [Krägefsky 2008, Chapter 7]) and the preceding high export (Jacquet et al. 2008) found at the EIFEX site initially. Thus, the initial conditions of EIFEX resemble those of the initial decline of a short-lived bloom. In this situation, a high coupling between growth and grazing is expected (Landry et al. 2000, Saito et al. 2005), as was found at the beginning of EIFEX.

In other Fe fertilization experiments where the initial $g: \mu$ ratio started lower, grazing rates lagged phytoplankton growth rates. Both grazing rates and protozooplankton biomass increased with time (Landry et al. 2000, Saito et al. 2005, Henjes et al. 2007). Different from IronEx II, SEEDS I and EisenEx, however, we found a close coupling between phytoplankton growth and microzooplankton grazing at 
the beginning that eased out with time because of decreasing grazing rates (Table 2). Total protozooplankton biomass also showed a decreasing tendency through EIFEX that was statistically non-significant (Table 3). However, this tendency was not the same for all groups. The decrease of small microzooplankton appears to explain the decrease in grazing rates (Tables 2 \& 3, Fig. 4, Pearson's $\mathrm{r}=0.82, \mathrm{p}=0.02, \mathrm{n}=7$ ). During EIFEX, there was a selective change from small to large protozooplankton that could reflect either a bottom-up or a top-down control on the protozooplankton population. The bottom-up control possibility should imply a change in the quantity or quality of the phytoplankton prey for protozooplankton. The absolute abundances of phytoplankton groups consisting of smaller cells, and perhaps preferred prey of small protozooplankton, remained more or less constant (Hoffmann et al. 2006). The major change in the phytoplankton population during EIFEX was an increase in diatoms. This result discards a significant effect of prey quality and quantity on protozooplankton dynamics and hints of a top-down control, most likely by mesozooplankton. Changes in protozooplankton population with time (Table 3) show that large, armored protozooplankton were positively selected through EIFEX, which also suggests a topdown control on microprotozooplankton. Considering the slopes from Table 3, a classification appears, following a gradient from stronger decreasing to higher increasing concentrations with time (hypothetically reflecting a classification from groups most preferentially grazed by mesozooplankton to the less preferred ones), as follows: small athecate dinoflagellates, large aloricate ciliates, small aloricate ciliates, small thecate dinoflagellates, large athecate dinoflagellates, tintinnids and large thecate dinoflagellates. This classification reveals a change from small, naked to large, armored forms of microprotozooplankton during EIFEX. It is now well established that copepods have higher clearance rates on microzooplankton than on phytoplankton, indicating positive grazing selection for microprotozooplankton (Fessenden \& Cowles 1994, Zeldis et al. 2002, Dagg et al. 2009). Mesozooplankton was already abundant at the beginning and increased in the fertilized patch from ca. $2.4 \mathrm{~g} \mathrm{C} \mathrm{m}^{-2}$ to ca. $4.3 \mathrm{~g} \mathrm{C} \mathrm{m}^{-2}$ in the 0 to $400 \mathrm{~m}$ layer (Krägefsky 2008, Chapter 7), increasing also their grazing pressure as measured by the enhanced production of fecal pellets (Assmy et al. 2013). The high and increasing abundance of mesozooplankton and their grazing selectivity for protozooplankton was likely the cause for the decrease in small protozooplankton, which resulted in the decreasing grazing rates during EIFEX.
The continuous increase in $\mu: g$ ratio (Table 2) also occurred in EisenEx (Henjes et al. 2007) but because growth increased more than grazing rates. Here, Assmy et al. (2007) hypothesized that predation of copepods on protozooplankton aided diatom biomass buildup. This pattern means that a higher proportion of primary production escapes microzooplankton control and is available to a more efficient exporting system towards the end of both Fe fertilization experiments. Subtracting the natural net growth rate (biomass accumulation) from the experimental net growth rate could provide an idea of the pattern of Phyto-C exported (Fig. 5), i.e. it represents the Phyto$\mathrm{C}$ not grazed by microzooplankton that did not result in bloom buildup. The increase in phytoplankton biomass available to the system because of decreasing grazing by microzooplankton together with the halt and posterior decrease in the biomass of the bloom strongly suggests that a large portion of the primary production (ca $75 \%$ at $20 \mathrm{~m}$ depth) was being exported during the last days of EIFEX. In agreement, Smetacek et al. (2012) reported a strong increase in carbon export out of the upper $100 \mathrm{~m}$ layer in the last $12 \mathrm{~d}$ of EIFEX (Days 24 to 36), with an average carbon flux of $1.4 \mathrm{~g} \mathrm{~m}^{-2} \mathrm{~d}^{-1}$. Our estimate of export derived from dilution experiments net carbon synthesis that is not incorporated into the carbon stock buildup is $0.013 \mathrm{~g} \mathrm{~m}^{-3} \mathrm{~d}^{-1}$ for the $20 \mathrm{~m}$ depth on Days 27 to 35 (Fig. 5b), or $1.3 \mathrm{~g} \mathrm{~m}^{-2} \mathrm{~d}^{-1}$ if extrapolated to the upper $100 \mathrm{~m}$ mixed layer. It is not straightforward to extrapolate results from a single depth to the total mixed layer, although the $20 \mathrm{~m}$ depth appears as the most representative single depth of the water column in terms of light (see above). A comparison of our estimates of carbon export fluxes for the first part of EIFEX with those of Smetacek et al. (2012) would give $0.3 \mathrm{~g} \mathrm{~m}^{-2} \mathrm{~d}^{-1}$ until Day 27 (Fig. 5a) and $0.2 \mathrm{~g} \mathrm{~m}^{-2}$ $\mathrm{d}^{-1}$ (Table 1 from Smetacek et al. 2012), respectively. The close match between the temporal patterns of our estimates and the measured export fluxes reported by Smetacek et al. (2012) supports the results presented here in terms of flux dynamics.

The results from EisenEx and EIFEX suggest that ephemeral Fe fertilization produces a response of microprotozooplankton, while a longer fertilization would allow for an increase in mesozooplankton, which in turn would decrease microzooplankton control on phytoplankton and produce a shift towards a system with higher exporting capabilities. The effect of the microprotozooplankton-mesozooplankton relationship on net primary production observed in EIFEX also reveals the importance of this link in the fate of Phyto- $\mathrm{C}$ and, thus, in the 
dynamics between recycling and exporting systems (Calbet \& Saiz 2005).

In summary, Fe fertilization resulted in a large accumulation of phytoplankton, mainly diatoms. The measured intrinsic growth rates were low (average $=$ $0.23 \mathrm{~d}^{-1}$ ) but typical of the zone and the species present. There was no clear pattern in growth rates throughout the experiment, although the lowest rates were measured during the last days coinciding with the demise of the bloom. The close coupling between growth and grazing rates together with other chemical and biological variables suggest that we encountered the initial decline of a short-lived bloom at the onset of the Fe fertilization. Grazing rates decreased during the experiment along with small protozooplankton abundances, which in turn matched the increase in mesozooplankton abundance. We suggest that mesozooplankton grazing on small microzooplankton was part of the reason for the increase in decoupling between phytoplankton growth and microzooplankton grazing and for the shift from a recycling towards a more exporting system.

Acknowledgements. We thank the captain and crew of the $\mathrm{R} / \mathrm{V}$ 'Polarstern' for their invaluable help during the cruise. We extend our gratitude to V. Strass and colleagues for CTD sampling, F. Colijn for his generosity in sharing the Cytobuoy flow cytometer and U. Bathmann for logistic preparation of the cruise. Our colleagues on board made life much more bearable in appalling seas. Three anonymous reviewers provided valuable comments to improve the manuscript. This work was partly supported by Spanish Ministry of Education (MEC) research grant REN2002-12076-E/ANT and by the Alfred Wegener Institute Helmholtz Center for Polar and Marine Research.

\section{LITERATURE CITED}

- Archer SD, Verity PG, Stefels J (2000) Impact of microzooplankton on the progression and fate of the spring bloom in fjords of northern Norway. Aquat Microb Ecol $22: 27-41$

> Assmy P, Henjes J, Klaas C, Smetacek V (2007) Mechanisms determining species dominance in a phytoplankton bloom induced by the iron fertilization experiment EisenEx in the Southern Ocean. Deep-Sea Res I 54:340-362

> Assmy P, Smetacek V, Montresor M, Klaas C and others (2013) Thick-shelled, grazer-protected diatoms decouple ocean carbon and silicon cycles in the iron-limited Antarctic Circumpolar Current. Proc Natl Acad Sci USA 110:20633-20638

Becquevort S (1997) Nanoprotozooplankton in the Atlantic sector of the Southern Ocean during early spring: biomass and feeding activities. Deep-Sea Res II 44:355-373

Bjornsen PK, Kuparinen J (1991) Determination of bacterioplankton biomass, net production and growth efficiency in the Southern Ocean. Mar Ecol Prog Ser 71:185-194

Boyd P, Crossley A, DiTullio G, Griffiths F and others (2001)
Control of phytoplankton growth by iron supply and irradiance in the subantarctic Southern Ocean: experimental results from the SAZ Project. J Geophys Res 106:31573-31583

- Boyd PW, Jickells T, Law CS, Blain S and others (2007) Mesoscale iron enrichment experiments 1993-2005: synthesis and future directions. Science 315:612-617

Calbet A, Landry MR (2004) Phytoplankton growth, microzooplankton grazing, and carbon cycling in marine systems. Limnol Oceanogr 49:51-57

Calbet A, Saiz E (2005) The ciliate-copepod link in marine ecosystems. Aquat Microb Ecol 38:157-167

Cassar N, Bender ML, Barnett BA, Fan S, Moxim WJ, Levy H II, Tilbrook B (2007) The Southern Ocean biological response to aeolian iron deposition. Science 317:1067-1070

Cisewski B, Strass VH, Losch M, Prandke H (2008) Mixed layer analysis of a mesoscale eddy in the Antarctic Polar Front Zone. J Geophys Res 113:C05017, doi:10.1029/ 2007JC004372

Coale KH, Johnson KS, Chavez FP, Buesseler KO and others (2004) Southern Ocean Iron Enrichment Experiment: carbon cycling in high- and low-Si waters. Science 304: 408-414

Dagg M, Strom S, Liu HB (2009) High feeding rates on large particles by Neocalanus flemingeri and N. plumchrus, and consequences for phytoplankton community structure in the subarctic Pacific Ocean. Deep-Sea Res I 56:716-726

de Baar HJW, Boyd PW, Coale KH, Landry MR and others (2005) Synthesis of iron fertilization experiments: from the Iron Age in the Age of Enlightenment. J Geophys Res 110:C09S16, doi:10.1029/2004JC002601

Edler L (ed) (1979) Recommendations on methods for marine biological studies in the Baltic Sea: phytoplankton and chlorophyll. BMB Publ No. 5, University of Stockholm

Fessenden L, Cowles TJ (1994) Copepod predation on phagotrophic ciliates in Oregon coastal waters. Mar Ecol Prog Ser 107:103-111

Fonda-Umani S, Beran A (2003) Seasonal variations in the dynamics of microbial plankton communities: first estimates from experiments in the Gulf of Trieste, Northern Adriatic Sea. Mar Ecol Prog Ser 247:1-16

$>$ Frost BW (1972) Effects of size and concentration of food particles on the feeding behavior of the marine planktonic copepod Calanus pacificus. Limnol Oceanogr $17: 805-815$

Gallegos CL (1989) Microzooplankton grazing on phytoplankton in the Rhode River, Maryland: nonlinear feeding kinetics. Mar Ecol Prog Ser 57:23-33

Gervais F, Riebesell U, Gorbunov MY (2002) Changes in primary productivity and chlorophyll $a$ in response to iron fertilization in the Southern Polar Frontal Zone. Limnol Oceanogr 47:1324-1335

Goericke R, Montoya JP (1998) Estimating the contribution of microalgal taxa to chlorophyll $a$ in the field-variations of pigment ratios under nutrient- and light-limited growth. Mar Ecol Prog Ser 169:97-112

> Gutiérrez-Rodríguez A, Latasa M, Estrada M, Vidal M, Marrase C (2010) Carbon fluxes through major phytoplankton groups during the spring bloom and postbloom in the northwestern Mediterranean Sea. DeepSea Res I 57:486-500

Hall JA, Safi K (2001) The impact of in situ Fe fertilisation on the microbial food web in the Southern Ocean. Deep-Sea Res II 48:2591-2613 
Harris R, Wiebe P, Lenz J, Skjoldal HR, Huntley M (eds) (2000) ICES zooplankton methodology manual. Academic Press, San Diego, CA

> Henjes J, Assmy P, Klaas C, Verity P, Smetacek V (2007) Response of microzooplankton (protists and small copepods) to an iron-induced phytoplankton bloom in the Southern Ocean (EisenEx). Deep-Sea Res I 54:363-384

> Hillebrand $\mathrm{H}$, Durselen CD, Kirschtel D, Pollingher U, Zohary T (1999) Biovolume calculation for pelagic and benthic microalgae. J Phycol 35:403-424

Hoffmann LJ, Peeken I, Lochte K, Assmy P, Veldhuis M (2006) Different reactions of Southern Ocean phytoplankton size classes to iron fertilization. Limnol Oceanogr 51:1217-1229

> Hoffmann LJ, Peeken I, Lochte K (2007) Effects of iron on the elemental stoichiometry during EIFEX and in the diatoms Fragilariopsis kerguelensis and Chaetoceros dichaeta. Biogeosciences 4:569-579

> Jacquet SHM, Savoye N, Dehairs F, Strass VH, Cardinal D (2008) Mesopelagic carbon remineralization during the European iron fertilization experiment. Global Biogeochem Cycles 22:GB1023, doi:10.1029/2006GB002902

> Keller MD, Selvin RC, Claus W, Guillard RRL (1987) Media for the culture of oceanic ultraphytoplankton. J Phycol 23:633-638

Krägefsky S (2008) On the copepod response to ironinduced phytoplankton blooms in the Southern Ocean. $\mathrm{PhD}$ thesis, University of Bremen

Landry MR, Hassett RP (1982) Estimating the grazing impact of marine microzooplankton. Mar Biol 67:283-288

> Landry MR, Constantinou J, Latasa M, Brown SL, Bidigare RR, Ondrusek ME (2000) Biological response to iron fertilization in the eastern equatorial Pacific (IronEx II). III. Dynamics of phytoplankton growth and microzooplankton grazing. Mar Ecol Prog Ser 201:57-72

- Landry MR, Selph KE, Brown SL, Abbott MR and others (2002) Seasonal dynamics of phytoplankton in the Antarctic Polar Front region at $170^{\circ} \mathrm{W}$. Deep-Sea Res II 49:1843-1865

> Latasa M (2014) Comment: a potential bias in the databases of phytoplankton growth and microzooplankton grazing rates because of the improper formulation of the null hypothesis in dilution experiments. Limnol Oceanogr 59:1092-1094

> Latasa M, Van Lenning K, Garrido J, Scharek R, Estrada M, Rodríguez F, Zapata M (2001) Losses of chlorophylls and carotenoids in aqueous acetone and methanol extracts prepared for RPHPLC analysis of pigments. Chromatographia 53:385-391

> Latasa M, Moran XAG, Scharek R, Estrada M (2005) Estimating the carbon flux through main phytoplankton groups in the northwestern Mediterranean. Limnol Oceanogr 50:1447-1458

Le Quéré C, Harrison SP, Prentice IC, Buitenhuis ET and others (2005) Ecosystem dynamics based on plankton functional types for global ocean biogeochemistry models. Glob Change Biol 11:2016-2040, doi:10.1111/j.13652486.2005.1004.x

Martin JH, Coale KH, Johnson KS, Fitzwater SE and others (1994) Testing the iron hypothesis in ecosystems of the equatorial Pacific Ocean. Nature 371:123-129

Martin P, Rutgers van der Loeff M, Cassar N, Vandromme P and others (2013) Iron fertilization enhanced net community production but not downward particle flux during the Southern Ocean iron fertilization experiment LOHAFEX. Global Biogeochem Cycles 27:871-881

- Menden-Deuer S, Lessard EJ (2000) Carbon to volume relationships for dinoflagellates, diatoms, and other protist plankton. Limnol Oceanogr 45:569-579

Moigis AG (2006) The clearance rate of microzooplankton as the key element for describing estimated non-linear dilution plots demonstrated by a model. Mar Biol 149: 743-762

$>$ Peloquin J, Hall J, Safi K, Ellwood M and others (2011) Control of the phytoplankton response during the SAGE experiment: a synthesis. Deep-Sea Res II 58:824-838

> Redden AM, Sanderson BG, Rissik D (2002) Extending the analysis of the dilution method to obtain the phytoplankton concentration at which microzooplankton grazing becomes saturated. Mar Ecol Prog Ser 226:27-33

Saito H, Suzuki K, Hinuma A, Ota T and others (2005) Responses of microzooplankton to in situ iron fertilization in the western subarctic Pacific (SEEDS). Prog Oceanogr 64:223-236

Sherr EB, Sherr BF (2007) Heterotrophic dinoflagellates: a significant component of microzooplankton biomass and major grazers of diatoms in the sea. Mar Ecol Prog Ser 352:187-197

Smetacek V, Assmy P, Henjes J (2004) The role of grazing in structuring Southern Ocean pelagic ecosystems and biogeochemical cycles. Antarct Sci 16:541-558

> Smetacek V, Klaas C, Strass VH, Assmy P and others (2012) Deep carbon export from a Southern Ocean iron-fertilized diatom bloom. Nature 487:313-319

Stoecker DK, Capuzzo JM (1990) Predation on protozoa: its importance to zooplankton. J Plankton Res 12:891-908

> Strom SL, Miller CB, Frost BW (2000) What sets lower limits to phytoplankton stocks in high-nitrate, low-chlorophyll regions of the open ocean? Mar Ecol Prog Ser 193:19-31

Strom SL, Brainard MA, Holmes JL, Olson MB (2001) Phytoplankton blooms are strongly impacted by microzooplankton grazing in coastal North Pacific waters. Mar Biol 138:355-368

Throndsen J (1995) Estimating cell numbers. In: Hallegraeff G M, Anderson DM, Cembella AD (eds) Manual on harmful marine microalgae. IOC manuals and guides No. 33, UNESCO, Paris, p 63-80

Timmermans KR, Gerringa LJA, de Baar HJW, van der Wagt B and others (2001) Growth rates of large and small Southern Ocean diatoms in relation to availability of iron in natural seawater. Limnol Oceanogr 46:260-266

> Tsuda A, Takeda S, Saito H, Nishioka J and others (2007) Evidence for the grazing hypothesis: grazing reduces phytoplankton responses of the HNLC ecosystem to iron enrichment in the western subarctic Pacific (SEEDS II). J Oceanogr 63:983-994

> Wells ML, Trick CG, Cochlan WP, Beall B (2009) Persistence of iron limitation in the western subarctic Pacific SEEDS II mesoscale fertilization experiment. Deep-Sea Res II 56:2810-2821

Zapata M, Rodriguez F, Garrido JL (2000) Separation of chlorophylls and carotenoids from marine phytoplankton: a new HPLC method using a reversed phase $\mathrm{C}_{8}$ column and pyridine-containing mobile phases. Mar Ecol Prog Ser 195:29-45

Zeldis J, James MR, Grieve J, Richards L (2002) Omnivory by copepods in the New Zealand Subtropical Frontal Zone. J Plankton Res 24:9-23

Submitted: September 24, 2013; Accepted: July 9, 2014

Proofs received from author(s): September 30, 2014
Editorial responsibility: Steven Lohrenz, New Bedford, Massachusetts, USA 